\title{
Antioxidant and antihypertensive activities of wonderful cola (Buchholzia coriacea) seed protein and enzymatic protein hydrolysates
}

\author{
Oluwole S. Ijarotimi ${ }^{\mathrm{a}}$, Sunday A. Malomo ${ }^{\mathrm{a}, \mathrm{b}}$, Adeola M. Alashi ${ }^{\mathrm{b}}$, Ifeanyi D. Nwachukwu ${ }^{\mathrm{b}}$, \\ Tayo N. Fagbemi ${ }^{\mathrm{a}}$, Oluwatooyin F. Osundahunsi ${ }^{\mathrm{a}}$ and Rotimi E. Aluko ${ }^{\mathrm{b}^{*}}$
}

\begin{abstract}
aDepartment of Food Science and Technology, Federal University of Technology, Akure, Ondo State, Nigeria bepartment of Food and Human Nutritional Sciences, University of Manitoba, Winnipeg, Manitoba, Canada R3T 2N2

${ }^{*}$ Corresponding author: Dr. Rotimi E. Aluko, Department of Food and Human Nutritional Sciences, University of Manitoba, Winnipeg, Manitoba, Canada R3T 2N2. Tel: +1-204-474-9555; Fax: +1-204-474-7593; E-mail: rotimi.aluko@umanitoba.ca

DOI: $10.31665 / J F B .2018 .3156$

Received: July 02, 2018; Revised received \& accepted: September 04, 2018

Citation: Ijarotimi, O.S., Malomo, S.A., Alashi, A.M., Nwachukwu, I.D., Fagbemi, T.N., Osundahunsi, O.F., and Aluko, R.E. (2018). Antioxidant and antihypertensive activities of wonderful cola (Buchholzia coriacea) seed protein and enzymatic protein hydrolysates. J. Food Bioact. 3: 133-143.
\end{abstract}

\begin{abstract}
The aim of this work was to produce wonderful cola protein hydrolysate fractions with in vitro antioxidant properties coupled with blood pressure-reducing ability when orally administered to spontaneously hypertensive rats (SHRs). Wonderful cola protein isolate (WCl) was hydrolyzed with pancreatin to produce a hydrolysate $(\mathrm{WCH})$, which was subjected to ultrafiltration separation using 1, 3, 5, and $10 \mathrm{kDa}$ molecular weight cut-off membranes to obtain $<1,1-3,3-5$ and 5-10 kDa peptide fractions, respectively. The $<1$ and $1-3 \mathrm{kDa}$ fractions had higher contents of arginine when compared to the 3-5 and 5-10 kDa peptides. The $\mathrm{WCH}$ and $<1 \mathrm{kDa}$ peptide fraction had significantly $(p<0.05)$ better DPPH radical scavenging (55-67\%) and metal chelation (83-93\%) activities but lower hydroxyl radical scavenging power (10-32\%) than the $\mathrm{WCl}(46,46$ and $63 \%$, respectively). The $<1 \mathrm{kDa}$ had significantly $(p<0.05)$ higher in vitro inhibition $(80 \%)$ of angiotensin converting enzyme (ACE) activity while the 5-10 kDa was the most active inhibitor $(90 \%)$ of renin activity. All peptide fractions so produced had better systolic and diastolic blood pressure-lowering effects than $\mathrm{WCH}$ and $\mathrm{WCl}$. However, the $<1 \mathrm{kDa}$ fraction produced significantly $(\mathrm{p}<0.05)$ stronger systolic $(-33 \mathrm{mmHg})$ and diastolic $(-30 \mathrm{mmHg})$ blood pressure reductions $6 \mathrm{~h}$ after oral gavage to SHRs. Thus, wonderful cola proteins contain encrypted bioactive peptides that may be used to formulate antioxidant and antihypertensive products.
\end{abstract}

Keywords: Wonderful cola; Buchholzia coriacea; Protein hydrolysate; Antioxidant; Renin; Angiotensin converting enzyme; Spontaneously hypertensive rats.

\section{Introduction}

The excesive activities of renin and angiotensin-coverting enzymes (ACE) have been implicated in the pathogenesis of high blood pressure (BP) leading to hypertension, a chronic disease that has globally claimed many lives (WHO, 2013). Accummulation of free radicals has been implicated in the health issues because it leads to oxidative stress, a cause and consequence of hypertension (Girgih et al., 2014a; Nabha et al., 2005). Hypertension occurs when the systolic BP (SBP) and diastolic BP (DBP) are $\geq 140$ and $\geq 90 \mathrm{mmHg}$, respectively (Pickering et al., 2005). The role of the renin-angiotensin system (RAS) in maintaining cardiovascular homeostasis involves renin-catalyzed conversion of the zymogen, angiotesinogen into angiotensin I, which is then hydrolyzed to pro- 
duce the required level (but not in excess amount) of angiotensin II (Acharya et al., 2003).

A high level of oxidative stress in the body is also reported to induce cardiovascular and renal damage with associated increase in blood pressure, which leads to hypertension (Nabha et al., 2005). Besides, free radicals affect the physiological conditions of the body through extensive oxidation of critical biopolymers, such as DNA, membrane lipids, structural proteins and enzymes while finally shutting down the body's normal cellular processes (Kregel and Zhang, 2007; Simão et al., 2011; Winczura et al., 2012). Therefore, some therapies based on free radical scavenging have been suggested as potential agents in the management of vascular damage-associated diseases such as hypertension (Nabha et al., 2005).

Several studies have reported the potential cardiovascular health benefits of plant-derived bioactive peptides with inhibitory activities against renin and ACE in addition to antioxidant effects (Arise et al., 2016; Malomo et al., 2015; Girgih et al., 2014a,b; He et al., 2013a,b; Valdez-Ortiz et al., 2012; Mäkinen et al., 2012; Alashi et al., 2014a,b; Jimsheena and Gowda, 2011; Jamdar et al., 2010; Zhu et al., 2010; Segura et al., 2010). The projected health benefits of these peptides are associated with their low molecular weight, low cost, and easy absorption into blood circulation coupled with little or no negative side effects as well as the ability to inhibit elements of RAS and effective antioxidant activities.

Wonderful cola (Buchholzia coriacea) seed is one of the underutilized but readily available crops that has the potential (Ijarotimi et al., 2017), as a raw material, for the manufacture of bioactive protein hydrolysates. Our previous work examined the physicochemical and functional properties of wonderful cola seed protein isolate (WCI) obtained by isoelectric precipitation technique. The study revealed that WCI possesses high in vitro protein digestibility and solubility coupled with strong functional (foaming and emulsion) properties at very low concentrations $(10-20 \mathrm{mg} / \mathrm{mL})$ and within hydrophilic ( $\mathrm{pH}$ 7-9) environments (Ijarotimi et al., 2017). Although the seed has a low protein content of 13\% (Ezekiel and Onyeoziri, 2009), its use in hypertension management has been reported (Adisa et al., 2010). Besides, several studies have also reported other health benefits of the seeds (Fred-Jaiyesimi et al., 2011; Adisa et al., 2010; Ezekiel and Onyeoziri, 2009; Ajaiyeoba et al., 2001). However, information is lacking on the specific wonderful cola compounds (proteins, polyphenols, polysaccharides, etc) that are responsible for these bioactivities.

There is therefore, paucity of information on potential use of wonderful cola seed protein and its enzymatically liberated peptides as bioactive agents that can ameliorate cardiovascular health diseases. Thus the aim of this study was to enzymatically hydrolyze the wonderful cola proteins to produce a protein hydrolysate with antioxidant and antihypertensive properties. The protein hydrolysate was also fractionated into different peptide sizes by membrane ultrafiltration to study the relationship between the molecular size and bioactivity (function) of peptides.

\section{Materials and methods}

\subsection{Materials}

Wonderful cola seeds were purchased from Ojee market, Ibadan, Nigeria, followed by authentication in the Department of Botany, University of Ibadan, Ibadan, Nigeria. Human recombinant renin was purchased from Cayman Chemical Co. (Ann Arbor, MI, USA) while other enzymes such as pancreatin and ACE (rabbit lung) were purchased from Sigma-Aldrich (St. Louis, MO, USA). Other analytical-grade reagents were obtained from Fisher Scientific (Oakville, ON, Canada).

\subsection{Preparation of wonderful cola seed flour (WCF)}

Fresh wonderful cola seeds were cleaned by the double disinfection method as previously reported (Ijarotimi et al., 2017). They were washed thoroughly with distilled water to remove adhering particles, re-washed with aqueous sodium hypochlorite to remove surface contamination and further rinsed again with distilled water. The cleaned seeds were oven dried at $60{ }^{\circ} \mathrm{C}$ (Plus11 Sanyo Gallenkamp PLC, UK) for $8 \mathrm{~h}$, milled (Philips laboratory blender, HR2811 model) and sieved using a $60 \mathrm{~mm}$ mesh sieve (British Standard) to obtain $\mathrm{WCF}$, which was stored at $-20{ }^{\circ} \mathrm{C}$ until used for protein extraction.

\subsection{Preparation of wonderful cola seed protein isolate (WCI)}

WCI was produced from WCF according to the method of Malomo et al. (2014) with slight modifications as described by Ijarotimi et al. (2017). WCF was dispersed in deionized water $(1: 20, \mathrm{w} / \mathrm{v})$ and the dispersion was adjusted to $\mathrm{pH} 8.0$ using $2 \mathrm{M} \mathrm{NaOH}$ to solubilize the proteins while stirring at $37^{\circ} \mathrm{C}$ for $2 \mathrm{~h}$; this was followed by centrifugation $\left(7000 \times \mathrm{g}, 60 \mathrm{~min}\right.$ at $\left.4{ }^{\circ} \mathrm{C}\right)$. The precipitate was discarded while the supernatant was filtered, adjusted to $\mathrm{pH}$ 5.0 with $2 \mathrm{M} \mathrm{HCl}$ to precipitate the proteins and then centrifuged $\left(7000 \times \mathrm{g}, 60 \mathrm{~min}\right.$ at $\left.4{ }^{\circ} \mathrm{C}\right)$. The resultant precipitate was re-dispersed in deionized water, adjusted to $\mathrm{pH} 7.0$ with $2 \mathrm{M} \mathrm{NaOH}$ and freeze-dried to obtain the WCI. Protein concentrations of the WCI and WCF were determined using the modified Lowry method (Markwell et al., 1978).

\subsection{Preparation of wonderful cola protein hydrolysate (WCH) and ultrafiltration membrane protein fractions}

WCH was produced according to the method described by Malomo et al. (2015) with slight modifications as follows. WCI (5\%, $\mathrm{w} / \mathrm{v}$, protein weight basis) was suspended in deionized water in a glass beaker equipped with a stirrer, heated to $37^{\circ} \mathrm{C}$ and adjusted to $\mathrm{pH} 7.5$ with $2 \mathrm{M} \mathrm{NaOH}$. Pancreatin was added to the mixture at 4:100 (E/S) ratio based on WCI protein content and digestion carried out for $4 \mathrm{~h}$. During digestion, the required $\mathrm{pH} 7.5$ was maintained constant by addition of the $\mathrm{NaOH}$ solution after which the enzymes were inactivated by adjusting to $\mathrm{pH} 4.0$ with $2 \mathrm{M}$ $\mathrm{HCl}$ followed by immersing the reaction vessel in boiling water bath for $10 \mathrm{~min}$. The undigested proteins were precipitated by centrifugation $\left(3500 \times \mathrm{g}, 60 \mathrm{~min}\right.$ at $\left.4{ }^{\circ} \mathrm{C}\right)$ after cooling and a portion of the supernatant (contains target peptides) was freeze dried as the $\mathrm{WCH}$, which was then stored at $-20{ }^{\circ} \mathrm{C}$. Protein content of the freeze dried $\mathrm{WCH}$ was determined using the modified Lowry method (Markwell et al., 1978). The remaining supernatant was sequentially passed through ultrafiltration membranes with molecular weight cut-off (MWCO) of 1, 3, 5, and $10 \mathrm{kDa}$ in an Amicon stirred ultrafiltration cell. Thus, the retentate from $1 \mathrm{kDa}$ membrane was passed through $3 \mathrm{kDa}$ membrane whose retentate was passed through $5 \mathrm{kDa}$ and the last retentate was then passed through $10 \mathrm{kDa}$ membrane to give permeates that have peptide sizes of $<1,1-3,3-5$, and 5-10 $\mathrm{kDa}$, respectively. The permeate from each MWCO membrane was collected, lyophilized, and stored at $-20^{\circ} \mathrm{C}$. 


\subsection{Amino acid composition analysis}

Amino acid profiles of the wonderful cola protein products were determined using the HPLC Pico-Tag system according to the method previously described after samples were digested with 6 $\mathrm{M} \mathrm{HCl}$ for $24 \mathrm{~h}$ (Bidlingmeyer et al., 1984). The cysteine and methionine contents were determined after performic acid oxidation (Gehrke et al., 1985) while the tryptophan content was determined after alkaline hydrolysis (Landry \& Delhaye, 1992).

\subsection{DPPH radical scavenging assay}

The scavenging effect of wonderful cola samples against 2,2- diphenyl-1-picryhydrazyl (DPPH) radical was measured according to the method of Aluko and Monu (2003). WCI, WCH, ultrafiltration fractions and glutathione $(\mathrm{GSH})$ stock solutions $(10 \mathrm{mg} / \mathrm{mL})$ were prepared in $1 \mathrm{~mL}$ of buffer $(0.1 \mathrm{M}$ sodium phosphate buffer, $\mathrm{pH} 7.0$ containing $1 \%$, w/v Triton X-100). DPPH was dissolved in methanol to a final concentration of $100 \mu \mathrm{M}$. Protein and peptide samples were mixed with $100 \mu \mathrm{L}$ of the DPPH solution in the 96well plate to give $1 \mathrm{mg} / \mathrm{mL}$ final assay concentration and incubated at room temperature in the dark for $30 \mathrm{~min}$. The blank consisted of $100 \mu \mathrm{L}$ of buffer instead of sample. Absorbance values of the blank and samples were read at $517 \mathrm{~nm}$ in a Synergy H4 multi-mode microplate reader (Biotek Instruments Inc., Winooski, VT, USA). The percent DPPH radical scavenging activity of each sample was determined using the following equation.

$$
\begin{gathered}
\text { DPPH radical scavenging activity }(\%)= \\
\left(1-\frac{\mathrm{A}_{517} \text { of sample }}{\mathrm{A}_{517} \text { of blank }}\right) \times 100
\end{gathered}
$$

\subsection{Chelation of metal ions}

The metal chelating activity was determined using the method of Xie et al. (2008), which was slightly modified as follows. Experimental samples and GSH (final assay concentration of $1 \mathrm{mg} / \mathrm{mL}$ ) were each combined with $0.05 \mathrm{~mL}$ of $2 \mathrm{mM} \mathrm{FeCl}_{2}$ and $1.85 \mathrm{~mL}$ double distilled water in a reaction tube. Ferrozine solution $(0.1$ $\mathrm{mL}$ of $5 \mathrm{mM}$ ) was added and mixed thoroughly. The mixture was then allowed to stand at room temperature for $10 \mathrm{~min}$ from which a $200 \mu \mathrm{L}$ aliquot was removed and added to a clear bottom 96well plate. A blank experiment was also conducted by replacing the sample with $1 \mathrm{~mL}$ of double distilled water. The absorbance values of blank (Ab) and sample (As) at $562 \mathrm{~nm}$ were measured in the Synergy H4 multi-mode microplate reader (Biotek Instruments Inc., Winooski, VT, USA) and the percentage chelating effect was calculated using the following equation.

$$
\begin{aligned}
& \text { Metal chelatingactivity }(\%)= \\
& \left(1-\frac{\mathrm{A}_{517} \text { of sample }}{\mathrm{A}_{517} \text { of blank }}\right) \times 100
\end{aligned}
$$

\subsection{Hydroxyl radical scavenging activity}

The hydroxyl radical scavenging activity was determined according to the method reported by Girgih et al. (2011a). Experimental samples, GSH and 1, 10-phenanthroline ( $3 \mathrm{mM})$ were each sepa- rately dissolved in $0.1 \mathrm{M}$ phosphate buffer ( $\mathrm{pH}$ 7.4) while $\mathrm{FeSO}_{4}$ $(3.0 \mathrm{mM})$ and $0.01 \%$ hydrogen peroxide were each separately dissolved in distilled water. An aliquot $(50 \mu \mathrm{L})$ of samples (s) at a final assay concentration of $1 \mathrm{mg} / \mathrm{mL}$ or buffer (blank, b) was first added to a clear, flat bottom 96 -well plate followed by $50 \mu \mathrm{L}$ of 1 , 10-phenanthroline and then $50 \mu \mathrm{L}$ of $\mathrm{FeSO}_{4}$. To initiate the Fenton reaction in the wells, $50 \mu \mathrm{L}$ of hydrogen peroxide was added to the mixture, covered and incubated at $37^{\circ} \mathrm{C}$ for $1 \mathrm{~h}$ with shaking. The absorbance was measured every $10 \mathrm{~min}$ for $1 \mathrm{~h}$ at $536 \mathrm{~nm}$ in a Varian Cary 50-UV/Visible spectrophotometer (Varian Inc., Belrose, NSW, Australia). The hydroxyl radical scavenging activity was calculated using the reaction rate $(\Delta \mathrm{A} / \mathrm{min})$ equation below:

$$
\begin{aligned}
& \text { OH radical scavenging activity }(\%)= \\
& \left(\frac{\left(\Delta \mathrm{A}_{536} / \min \right) \mathrm{b}-\left(\Delta \mathrm{A}_{536} / \mathrm{min}\right) \mathrm{s}}{\left(\Delta \mathrm{A}_{536} / \min \right) \mathrm{b}}\right) \times 100
\end{aligned}
$$

\subsection{Determination of oxygen radical absorbance capacity (ORAC)}

The ORAC assay of the experimental samples was done according to the procedures reported by You et al. (2010) with the following modifications. Potassium phosphate buffer $(75 \mathrm{mM}, \mathrm{pH} 7.4)$ was used to prepare all reagents, standards, samples and the control. Five Trolox concentrations, between 6.25 and $100 \mu \mathrm{M}$ were used to prepare a calibration curve. Fluorescein $(0.082 \mu \mathrm{M})$ and 2,2-Azobis (2-methyl propionamidine) dihydrochlroride (AAPH) $(0.15 \mathrm{M})$ were prepared immediately before use. Rutin trihydrate $(10 \mu \mathrm{M})$ was used as the antioxidant standard. Fluorescein $(120$ $\mu \mathrm{L}$ ) was transferred into the wells followed by addition of $20 \mu \mathrm{L}$ of samples (1 mg/mL final concentration) or blank (buffer). The mixtures were incubated for $20 \mathrm{~min}$ at $37^{\circ} \mathrm{C}$ in the Synergy H4 multi-mode microplate reader (Biotek Instruments Inc., Winooski, VT, USA) and subsequently AAPH solution $(60 \mu \mathrm{L})$ was added to each well. Data were collected every min for a total of $50 \mathrm{~min}$. The ORAC values were expressed as Trolox equivalents (TE) using the standard curve.

\subsection{Ferric-reducing antioxidant property (FRAP)}

FRAP was determined according to Zhang et al. (2008) which was modified as follows. Experimental sample or GSH was dissolved in $0.2 \mathrm{M}$ phosphate buffer, $\mathrm{pH} 6.6$; an aliquot $(250 \mu \mathrm{L})$ was mixed with $250 \mu \mathrm{L}$ of the buffer and $250 \mu \mathrm{L}$ of $1 \%$ solution of potassium ferricyanide. The mixture was thoroughly mixed using a vortex machine and heated at $50{ }^{\circ} \mathrm{C}$ for $20 \mathrm{~min}$. After incubation, $250 \mu \mathrm{L}$ of $10 \%(\mathrm{w} / \mathrm{v})$ trichloroacetic acid (TCA) were added followed by $50 \mu \mathrm{L}$ of $0.1 \%$ (w/v) solution of ferric chloride in double distilled water and then $200 \mu \mathrm{L}$ of double distilled water were added. The solution was allowed to stand for $10 \mathrm{~min}$ at room temperature, after which it was centrifuged at $1000 \times \mathrm{g}$ for $10 \mathrm{~min}$. An aliquot $(200$ $\mu \mathrm{L}$ ) of the supernatant was transferred to a clear bottom 96-well plate and the absorbance was read at $700 \mathrm{~nm}$ in ae Synergy H4 multi-mode microplate reader (Biotek Instruments Inc., Winooski, VT, USA).

\subsection{Superoxide radical scavenging activity}

The superoxide scavenging activity was measured according to the method described by Xie et al. (2008) with slight modifica- 
tion. An aliquot $(80 \mu \mathrm{L})$ of the protein fraction sample or GSH was mixed ( $1 \mathrm{mg} / \mathrm{mL}$ final assay concentration) with $80 \mu \mathrm{L}$ of $50 \mathrm{mM}$ Tris- $\mathrm{HCl}$ buffer ( $\mathrm{pH} 8.3$ ) containing $1.0 \mathrm{mM}$ ethylenediaminetetraacetic acid (EDTA) directly into a clear bottom 96-well plate in the dark. Pyrogallol $(1.5 \mathrm{mM})$ was dissolved in $10 \mathrm{mM} \mathrm{HCl}$ and $40 \mu \mathrm{L}$ of it added to each well. The blank reaction contained only Tris- $\mathrm{HCl}$ buffer. The reaction rate $(\Delta \mathrm{A} / \mathrm{min})$ of the sample (s) and blank (b) was measured immediately in a Synergy H4 multi-mode microplate reader (Biotek Instruments Inc., Winooski, VT, USA) at $420 \mathrm{~nm}$ for $4 \mathrm{~min}$. at room temperature using the buffer as blank. The superoxide scavenging activity was calculated using the following equation.

$$
\begin{aligned}
& \text { Superoxide radical scavenging activity }= \\
& \left(\frac{\left(\Delta \mathrm{A}_{420} / \min \right) \mathrm{b}-\left(\Delta \mathrm{A}_{420} / \min \right) \mathrm{s}}{\left(\Delta \mathrm{A}_{420} / \min \right) \mathrm{b}}\right) \times 100
\end{aligned}
$$

\subsection{ACE inhibition assay}

The ability of WCH and ultrafiltration fractions to inhibit in vitro ACE activity was measured according to a spectrophotometric method using synthetic N-[3-(2-furyl)acryloyl]-L-phenylalanylglycyl-glycine (FAPGG) as the substrate (Sigma-Aldrich, St. Louis, MO, USA) as previously described (Holmquist et al., 1979). Briefly, $1 \mathrm{~mL}$ of $0.5 \mathrm{mM}$ FAPGG (dissolved in $50 \mathrm{mM}$ Tris- $\mathrm{HCl}$ buffer containing $0.3 \mathrm{M} \mathrm{NaCl}, \mathrm{pH} 7.5$ ) was mixed with $20 \mu \mathrm{L}$ of ACE (20 mU final reaction activity) and $200 \mu \mathrm{L}$ sample dissolved in the same buffer. The rate of decrease in absorbance at $345 \mathrm{~nm}$ was recorded for $2 \mathrm{~min}$ at room temperature using a Varian Cary 50-UV/Visible spectrophotometer. The buffer was used instead of sample solutions in the blank experiment. The concentration of sample that inhibited ACE activity by $50 \%\left(\mathrm{IC}_{50}\right)$ was calculated from a non-linear regression plot of percentage ACE activity versus sample concentrations using GraphPad Prism 6 (GraphPad Software, La Jolla, CA, USA). ACE activity was expressed as the rate of reaction $(\triangle \mathrm{A} / \mathrm{min})$ and inhibitory activity was calculated as shown below.

$$
\begin{aligned}
\operatorname{ACE} \text { inhibition }(\%) & =\left[1-\Delta \mathrm{A} \cdot \mathrm{min}^{-1} \text { (sample) }\right] \\
& \times 100 \Delta \mathrm{A} \cdot \mathrm{min}^{-1} \text { (blank) }
\end{aligned}
$$

where $\Delta \mathrm{A} \cdot \mathrm{min}^{-1}{ }_{\text {(sample) }}$ and $\Delta \mathrm{A} \cdot \mathrm{min}^{-1}{ }_{\text {(blank) }}$ represent ACE activity in the presence and absence of the samples, respectively.

\subsection{Renin inhibition assay}

In vitro inhibition of human recombinant renin activity was conducted using the Renin Inhibitor Screening Assay Kit (Cayman Chemical Co., Ann Arbor, MI, USA) according to Malomo et al. (2015). Prior to the assay, renin buffer was diluted in $50 \mathrm{mM}$ Tris- $\mathrm{HCl}, \mathrm{pH} 8.0$, containing $100 \mathrm{mM} \mathrm{NaCl}$. The renin protein solution was diluted 20 times with the assay buffer before use and pre-warmed to $37^{\circ} \mathrm{C}$ prior to initiating the reaction in a fluorometric microplate reader (Spectra MAX Gemini, Molecular Devices, Sunnyvale, CA, USA) maintained at $37{ }^{\circ} \mathrm{C}$. Before the reaction (i) $20 \mu \mathrm{L}$ substrate, $160 \mu \mathrm{L}$ assay buffer, and $10 \mu \mathrm{L}$ Milli-Q water were added to the background wells; (ii) $20 \mu \mathrm{L}$ substrate, $150 \mu \mathrm{L}$ assay buffer, and $10 \mu \mathrm{L}$ Milli-Q water were added to the blank wells; and (iii) $20 \mu \mathrm{L}$ substrate, $150 \mu \mathrm{L}$ assay buffer, and $10 \mu \mathrm{L}$ sample were added to the inhibitor wells. The reaction was initi- ated by adding $10 \mu \mathrm{L}$ renin to the blank and sample wells. The microplate was shaken for $10 \mathrm{~s}$ to mix, incubated at $37^{\circ} \mathrm{C}$ for 15 min, and the fluorescence intensity (FI) was recorded using a Synergy $\mathrm{H} 4$ microplate reader (Biotek Instruments Inc., Winooski, VT, USA) at excitation and emission wavelengths of 340 and $490 \mathrm{~nm}$, respectively. The concentration of sample that inhibited renin activity by $50 \%\left(\mathrm{IC}_{50}\right)$ was calculated from a non-linear regression plot of percentage renin activity versus peptide concentrations. The percentage renin inhibition was calculated as follows.

$$
\text { Renin inhibition }(\%)=\left[1-\mathrm{FI}_{(\text {(sample })}\right] \times 100 \mathrm{FI}_{\text {(sample) }}
$$

\subsection{BP-lowering effect of peptides in spontaneously hyperten- sive rats (SHRs)}

Animal experiments were carried out following the Canadian Council on Animal Care Ethics guidelines with a protocol approved by the University of Manitoba Animal Ethics Committee. The 30-week old male SHRs (Charles River Laboratories, Montreal, QC, Canada) with 340-380 g body weight (bw) were kept in the Animal Housing Facility at the Richardson Centre for Functional Foods and Nutraceuticals, University of Manitoba, Winnipeg, Canada, under a $12 \mathrm{~h}$ day and night cycle at $22 \pm 2{ }^{\circ} \mathrm{C}$ and were fed regular diet and tap water. The rats were divided into three groups with 4 rats per group: WCI, WCH or membrane fractions (test samples), captopril (positive control) and phosphate buffered saline (PBS, $\mathrm{pH}$ 7.4) as the negative control. The test samples (each at $200 \mathrm{mg} / \mathrm{kg}$ bw) and captopril (10 mg/kg bw) were each dissolved in $1 \mathrm{~mL}$ PBS and administered to the SHRs by oral gavage followed by measurement of SBP and DBP at 2, 4, 6, 8, and 24 $\mathrm{h}$ using the tail-cuff method in slightly anesthetized rats as previously described (Aukema et al., 2010). Prior to sample administration, the baseline (time-zero) SBP and DBP were determined. The changes in SBP and DBP $(\triangle \mathrm{SBP}$ and $\triangle \mathrm{DBP}, \mathrm{mmHg})$ were recorded by subtracting the baseline data from the data obtained at different time points.

\subsection{Statistical analysis}

Triplicate replications were used to obtain mean values and standard deviations. Statistical analysis was performed with SAS (Statistical Analysis Software 9.1) using one-way analysis of variance. Duncan's multiple-range test was carried out to compare the mean values for samples with significant differences taken at $\mathrm{P}<0.05$.

\section{Results and discussion}

\subsection{Amino acid composition}

Results of the amino acid composition of wonderful cola protein isolate, hydrolysate and its membrane fractions are reported in Table 1. The data showed a relationship between the molecular weight and amino acid composition of the protein products. For instance, the $<1 \mathrm{kDa}$ membrane fractions had significantly $(\mathrm{P}<$ $0.05)$ higher contents of aromatic and hydrophobic amino acids, especially Phe, Leu and Tyr $(10.59,10.06$ and 8.43 g / 100 g, respectively) when compared to other protein products and membrane fractions. It is noteworthy that relationships between the antioxidant activity of peptides and the molecular weight as well 
Table 1. Amino acid profile (g/100 g protein) of wonderful cola protein isolate (WCI), hydrolysate (WCH) and ultrafiltration fractions

\begin{tabular}{|c|c|c|c|c|c|c|}
\hline \multirow{2}{*}{ Amino acids } & \multirow{2}{*}{ WCI } & \multirow{2}{*}{ WCH } & \multicolumn{4}{|c|}{ Fractionated peptides } \\
\hline & & & $<1 \mathrm{kDa}$ & 1-3 kDa & $3-5 \mathrm{kDa}$ & 5-10 kDa \\
\hline Thr & $3.86 \pm 0.07$ & $3.76 \pm 0.02$ & $3.54 \pm 0.13$ & $3.90 \pm 0.03$ & $3.93 \pm 0.06$ & $4.11 \pm 0.11$ \\
\hline Val & $4.52 \pm 0.06$ & $4.79 \pm 0.19$ & $5.23 \pm 0.10$ & $5.35 \pm 0.19$ & $5.34 \pm 0.08$ & $5.39 \pm 0.10$ \\
\hline Met & $1.18 \pm 0.10$ & $1.19 \pm 0.07$ & $0.72 \pm 0.01$ & $0.82 \pm 0.01$ & $0.83 \pm 0.05$ & $0.79 \pm 0.00$ \\
\hline Ile & $3.96 \pm 0.02$ & $3.64 \pm 0.03$ & $3.96 \pm 0.03$ & $3.81 \pm 0.02$ & $4.54 \pm 0.26$ & $4.46 \pm 0.20$ \\
\hline Leu & $8.61 \pm 0.10$ & $7.68 \pm 0.19$ & $10.06 \pm 0.05$ & $8.67 \pm 0.28$ & $8.32 \pm 0.17$ & $7.41 \pm 0.34$ \\
\hline Phe & $7.14 \pm 0.02$ & $6.46 \pm 0.01$ & $10.59 \pm 0.39$ & $8.45 \pm 0.35$ & $7.56 \pm 0.04$ & $5.82 \pm 0.05$ \\
\hline His & $4.53 \pm 0.44$ & $3.63 \pm 0.30$ & $3.66 \pm 0.27$ & $3.63 \pm 0.25$ & $3.54 \pm 0.01$ & $3.93 \pm 0.02$ \\
\hline Lys & $4.49 \pm 0.05$ & $4.50 \pm 0.39$ & $3.79 \pm 0.00$ & $3.93 \pm 0.05$ & $3.98 \pm 0.02$ & $4.64 \pm 0.02$ \\
\hline Trp & $1.65 \pm 0.10$ & $1.51 \pm 0.22$ & $1.59 \pm 0.03$ & $1.90 \pm 0.08$ & $1.81 \pm 0.03$ & $1.64 \pm 0.01$ \\
\hline Arg & $8.43 \pm 0.08$ & $9.10 \pm 0.01$ & $10.74 \pm 0.03$ & $8.75 \pm 0.02$ & $7.46 \pm 0.37$ & $7.03 \pm 0.03$ \\
\hline Tyr & $5.62 \pm 0.01$ & $5.33 \pm 0.27$ & $8.43 \pm 0.20$ & $6.72 \pm 0.20$ & $6.53 \pm 0.34$ & $4.33 \pm 0.08$ \\
\hline Ser & $5.12 \pm 0.10$ & $4.92 \pm 0.05$ & $4.11 \pm 0.09$ & $4.67 \pm 0.11$ & $4.71 \pm 0.13$ & $4.99 \pm 0.00$ \\
\hline Glu & $13.93 \pm 0.15$ & $17.04 \pm 0.16$ & $13.12 \pm 0.21$ & $13.89 \pm 0.17$ & $14.52 \pm 0.09$ & $14.70 \pm 0.04$ \\
\hline Pro & $6.76 \pm 0.08$ & $6.62 \pm 0.32$ & $3.39 \pm 0.05$ & $5.58 \pm 0.07$ & $6.43 \pm 0.28$ & $7.67 \pm 0.18$ \\
\hline Gly & $4.59 \pm 0.34$ & $5.40 \pm 0.15$ & $4.33 \pm 0.27$ & $5.59 \pm 0.39$ & $5.42 \pm 0.20$ & $6.70 \pm 0.30$ \\
\hline Asp & $11.26 \pm 0.15$ & $10.21 \pm 0.19$ & $7.61 \pm 0.23$ & $9.81 \pm 0.12$ & $10.58 \pm 0.29$ & $11.69 \pm 0.12$ \\
\hline Ala & $4.34 \pm 0.20$ & $4.22 \pm 0.19$ & $5.13 \pm 0.07$ & $4.53 \pm 0.38$ & $4.50 \pm 0.05$ & $4.69 \pm 0.20$ \\
\hline Cys & $1.97 \pm 0.02$ & $1.84 \pm 0.05$ & $1.07 \pm 0.05$ & $1.31 \pm 0.08$ & $1.45 \pm 0.22$ & $1.59 \pm 0.01$ \\
\hline
\end{tabular}

as the amino acid content have previously been reported (He et al., 2013a; Je et al., 2005). In an earlier work, He et al. (2013a) reported a higher proportion of aromatic and hydrophobic amino acids for the $<1 \mathrm{kDa}$ rapeseed peptide fractions, which may enhance hydrophobic interactions with other compounds. Such interactions could improve radical scavenging activity, hydrogen donating capability and overall antioxidant potential of the peptides (Aleman et al., 2011). The high antioxidant power of these aromatic and hydrophobic amino acids (Tyr and Phe) has been reported to be due to their indole and phenol groups, which enhance hydrogendonation capacity (Siddeeg et al., 2015; Ajibola et al., 2011; Ren et al. 2008). Besides, ultrafiltration separation led to a significant $(\mathrm{P}<0.05)$ improvement in the arginine (a precursor of vasodilator nitric oxide) content of the $<1 \mathrm{kDa}$ peptide fraction. The higher arginine proportions of the $<1 \mathrm{kDa}$ fraction may contribute to blood pressure-lowering potential as previously observed for protein hydrolysates from hemp seed (Malomo et al., 2015) and flaxseed (Nwachukwu et al., 2014).

\subsection{DPPH and hydroxyl radicals-scavenging activity}

DPPH radical scavenging is considered a good in vitro model widely used to assess antioxidant efficacy in relatively short time (Sakanaka et al., 2005). Antioxidants, on interaction with the DPPH radical, transfer either an electron or hydrogen atom to DPPH, thus reducing it to become a stable diamagnetic molecule (Siddeeg et al., 2015; Naik et al., 2003). The percentage DPPH radical scavenging activity of ultrafiltration membrane protein fractions varied from $66.9 \%$ in $5-10 \mathrm{kDa}$ to $67.3 \%$ in $1-3 \mathrm{kDa}$ peptide fractions (Fig. 1a). The scavenging activities of the peptide fractions $(\sim 67 \%)$ were significantly $(\mathrm{P}<0.05)$ higher when compared to WCI and $\mathrm{WCH}$ (46.1 and 55.0\%, respectively) but significantly $(\mathrm{P}<0.05)$ lower than glutathione $(71.0 \%)$. The greater DPPH radical scavenging activity of $\mathrm{WCH}$ and peptide fractions when compared to the unhydrolyzed WCI indicates that short-chain protein fragments are more effective at interacting with the DPPH radical than high molecular weight protein molecules. The increased DPPH radical scavenging ability of the peptide fractions when compared to the WCH suggests reduction in antagonistic peptide-peptide interactions after separation. Past findings also reported higher DPPH scavenging activities of hemp seed, zein, quinoa, chickpea and flaxseed ultrafiltration peptide fractions when compared to the unfractionated protein hydrolysates (Girgih et al., 2011a; Tang et al., 2010; Udenigwe et al., 2009; Wang et al., 2007; Aluko and Monu, 2003). However, the present results for peptide fractions ( 66\%) are higher than the $52 \%$ DPPH scavenging activity reported for a hemp seed meal hydrolysate (Girgih et al., 2014a). The stronger DPPH radical scavenging ability of the peptide fractions may be due to the presence of higher amounts of hydrophobic residues when compared to $\mathrm{WCH}$, since hydrophobicity could have enhanced peptide interactions with the DPPH molecules (Sarmadi and Ismail, 2010).

The hydroxyl radical, which is generated from interaction between $\mathrm{H}_{2} \mathrm{O}_{2}$ and metal ions such as $\mathrm{Fe}^{2+}$ or $\mathrm{Cu}^{2+}$ in the Fenton reaction, is believed to be an extremely reactive and short-lived species with destructive ability towards DNA, proteins, and lipids (Pastor et al., 2000; Huang et al., 2005; Jamdar et al., 2012). Thus, hydroxyl radical scavenging is imperative for protection against various oxidative stress-induced diseases (Girgih et al., 2013; Huang et al., 2005; Naqash and Nazeer, 2011). The results presented in Fig. 1b show that the hydroxyl radical scavenging activity of WCI, 


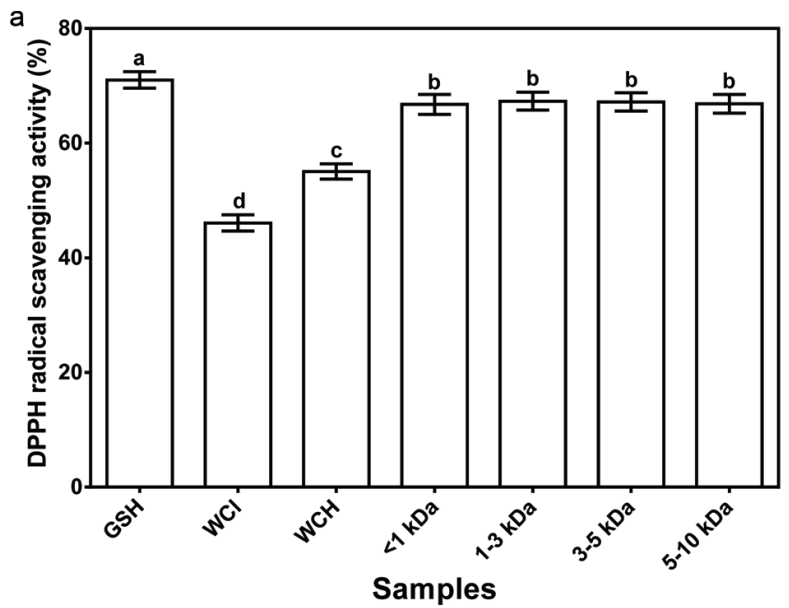

b

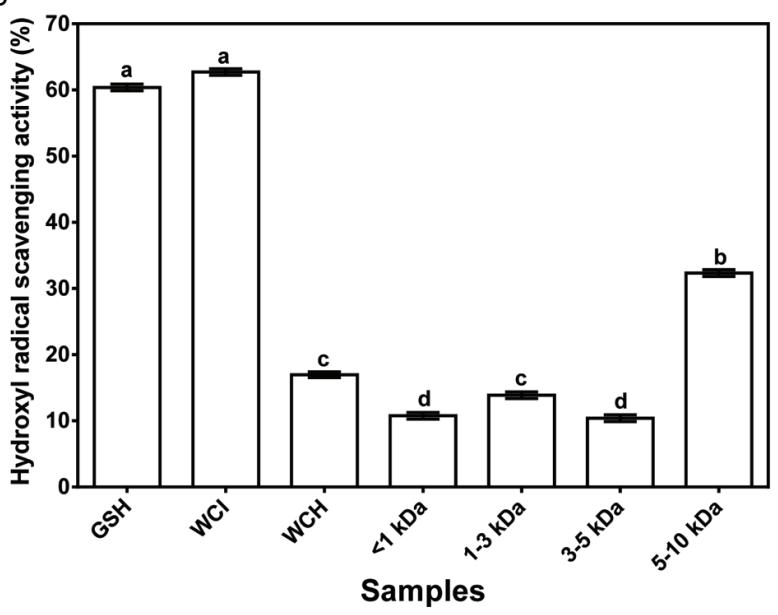

Figure 1. Free radical scavenging activity of glutathione (GSH), wonderful cola protein isolate (WCI), hydrolysate $(\mathrm{WCH})$ and ultrafiltration fractions. (a) DPPH; (b) Hydroxyl.

WCH, membrane fractions and GSH were $62.7,17 \%, 10.4-32.3$ and $60.4 \%$, respectively. The high hydroxyl radical scavenging activity of WCI (62.7\%) might be due to the synergistic effects of different long-chain protein fractions present in the isolates when compared to the shorter peptide chains in the protein hydrolysate and ultrafiltration fractions. The positive effect of cumulative interactions between several amino acids is further supported by the higher hydroxyl radical scavenging activity of the 5-10 kDa fraction, which contains longer peptide chains than the lower molecular weight peptide fractions. The present results are in contrast to those of a previous study (Xia et al., 2012) that reported a stronger hydroxyl radical scavenging activity for small size barley glutelinderived peptides than the high molecular weight peptides. The differences may be due to variations in the amino acid composition of the wonderful cola and barley glutelin samples.

\subsection{Ferric reducing antioxidant potential (FRAP) and Metal ion chelating activity}

Fig. 2a shows no significant differences $(\mathrm{P}>0.05)$ among the FRAP values for WCI, WCH and peptide fractions. However, all the samples had significantly $(\mathrm{P}<0.05)$ lower FRAP values than
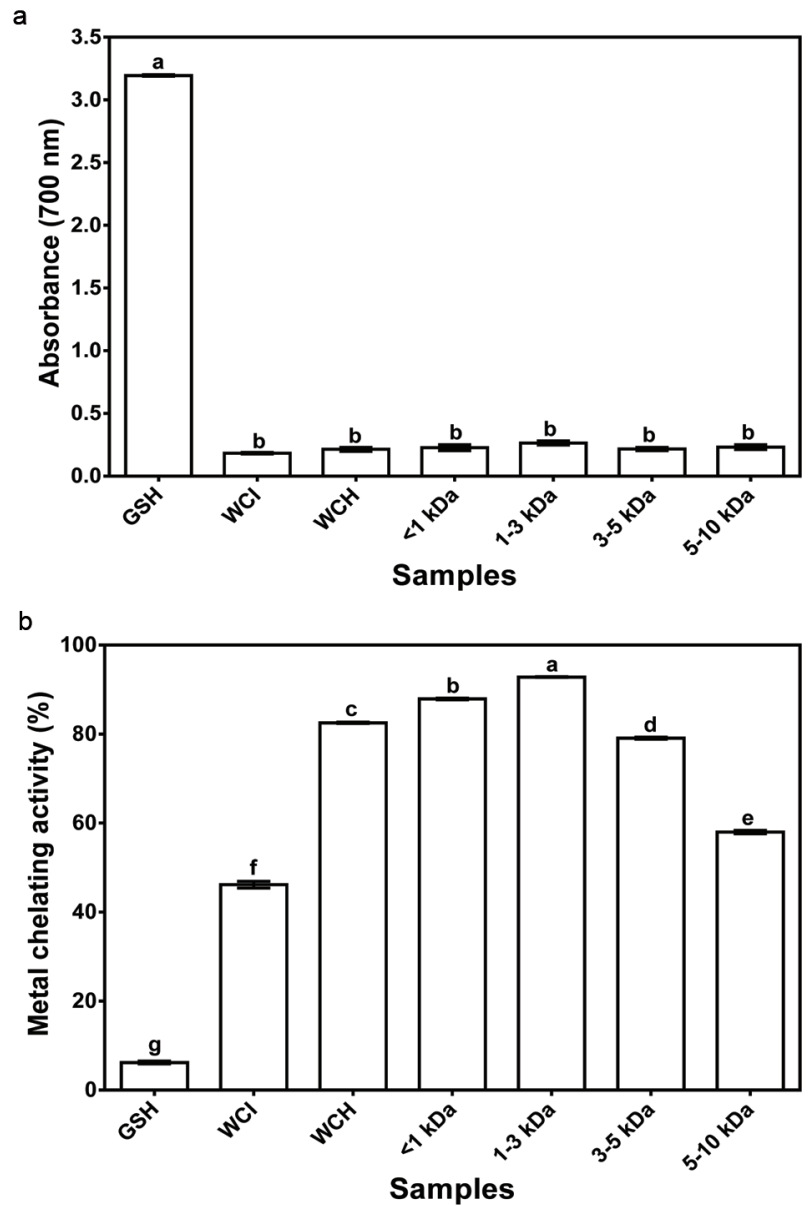

Figure 2. (a) Ferric reducing antioxidant power and (b) Metal chelation activity of glutathione (GSH), wonderful cola protein isolate (WCI), hydrolysate $(\mathrm{WCH})$ and ultrafiltration fractions.

glutathione, which suggest that the wonderful cola protein and peptides are poor reducing agents with respect to electron donation to ferric ion. The average FRAP value $(6.5 \%)$ of the wonderful cola samples is lower than the $13.65 \%$ reported for hemp seed peptide fractions (Girgih et al., 2013). The stronger ferric ion reducing ability of the hemp seed peptides may be due to amino acid composition differences when compared to the wonderful cola peptides.

The metal chelating activity of WCI and $\mathrm{WCH}$ were 46.2 and $82.9 \%$, respectively, while those of the peptide fractions varied from $58.0 \%$ for $5-10 \mathrm{kDa}$ to $92.8 \%$ for $1-3 \mathrm{kDa}$ (Fig. $2 \mathrm{~b}$ ). The stronger metal chelation activity of the $1-3 \mathrm{kDa}$ peptides cannot be explained strictly on the basis of amino acid composition. Therefore, the results may be explained on the basis of least peptidepeptide antagonistic effect in the $1-3 \mathrm{kDa}$ fraction, which would have enabled greater interactions with the metal ion. It is also possible that the arrangement of amino acids differs for the peptides present in various fractions, whereby the sequence in the $1-3 \mathrm{kDa}$ favored greater interactions with the metal ion than the sequence of peptides in other fractions. Comparatively, the metal chelating activity values of $\mathrm{WCI}, \mathrm{WCH}$ and membrane protein fractions are significantly $(\mathrm{P}<0.05)$ higher than that of glutathione $(6.2 \%)$. The results suggest greater metal binding efficacy as a result of synergistic effects of the different amino acid residues present in the cola protein, hydrolysate and peptide fractions when compared to 
a

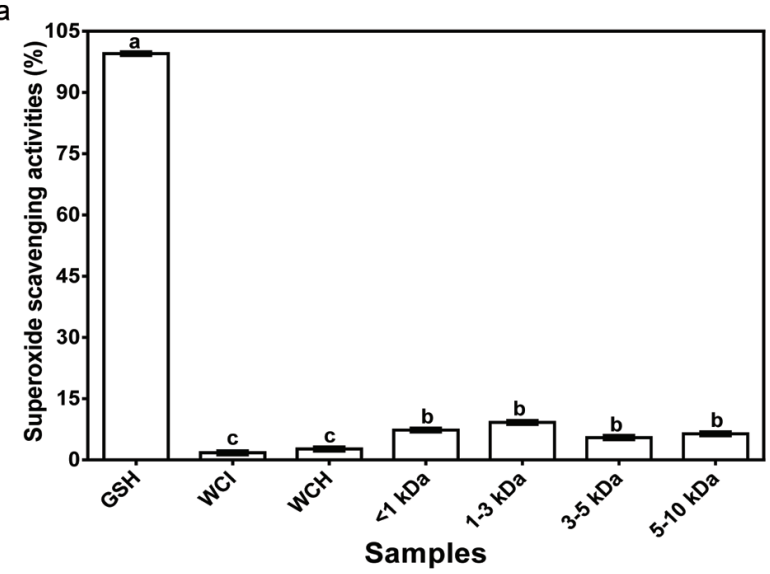

b

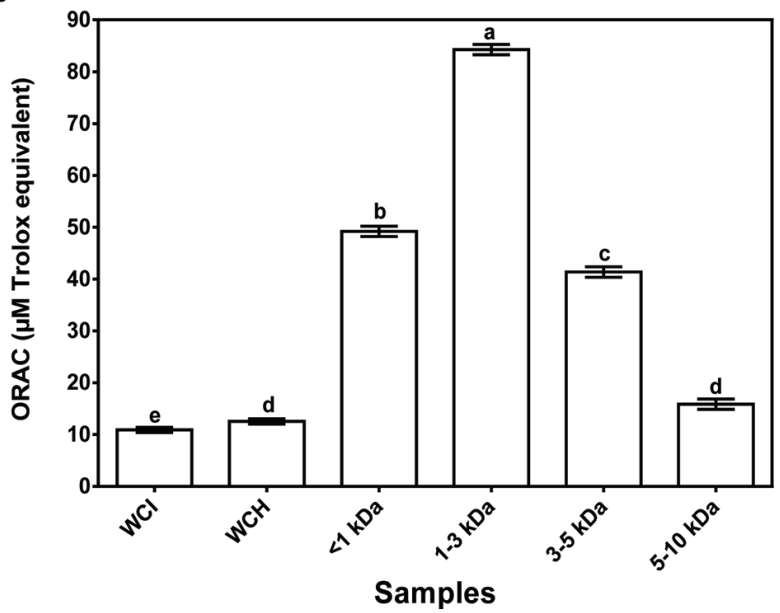

Figure 3. (a) Superoxide scavenging and (b) ORAC activities of glutathione (GSH), wonderful cola protein isolate (WCI), hydrolysate (WCH) and ultrafiltration fractions.

the single glutathione peptide. For example, the acidic and aromatic amino acids of the WCI protein or peptides present in WCH and membrane fractions might play a more important role in metal ion chelation when compared to the sulfhydryl group of glutathione.

\subsection{Superoxide radical scavenging activity and oxygen radical absorbance capacity (ORAC)}

The ability of wonderful kola and its protein membrane fractions to scavenge superoxide radical is shown in Fig. 3a. Superoxide, a precursor of highly reactive hydrogen peroxide and hydroxyl radicals, is a highly toxic radical specie generated by numerous biological reactions (Jamdar et al., 2012). There were no significant differences between the superoxide radical scavenging activity of the ultrafiltration peptide fractions, which suggest similar peptide synergism within the fractions. However, the peptide fractions had significantly $(\mathrm{P}<0.05)$ higher superoxide radical scavenging activity than the protein isolate and hydrolysate. Therefore, the results suggest peptide-peptide antagonistic effects within the $\mathrm{WCH}$, which was ameliorated by ultrafiltration separation. Similar results were reported for barley glutelin hydrolysate and peptide fractions (Xia et al., 2012). However, the superoxide radical scavenging activity of membrane fractions was significantly $(\mathrm{P}<0.05)$ less than that of glutathione $(99.5 \%)$, which suggests weak contributory effect of multiple amino acids in the peptide fractions in comparison to the 3 amino acids in glutathione.

The ORAC assay tests a compound's capacity to act as an antioxidant by quenching peroxyl radicals (ROO). This is assessed using fluorescence decay curve of the sample in comparison to a blank with no antioxidant activity and the results are normally reported as trolox equivalents (Sheih et al., 2009). With exception of the 5-10 $\mathrm{kDa}$ fractions, the peroxyl radical scavenging activity of fractionated peptides was significantly $(\mathrm{P}<0.05)$ higher than that of WCI or WCH (Fig. 3b). The present study showed that smaller size peptides $(<3 \mathrm{kDa})$ had stronger peroxyl radical scavenging activity when compared to larger size peptides (3-10 kDa). This observation has previously been reported to be as a result of the ability of small size peptides to interact with and donate electrons to free radicals more efficiently than the larger size peptides (Sheih et al., 2009). The stronger scavenging activity of the peptide fractions $(<5 \mathrm{kDa})$ also indicate reduced antagonist effect between the peptides when compared to the hydrolysate. In contrast, the larger size peptides in the $5-10 \mathrm{kDa}$ fraction may have negated the advantage of reductions in peptide antagonism, hence ORAC value was similar to that of the WCH.

\subsection{In vitro inhibition of renin and ACE activities}

Fig. 4a shows that the ACE-inhibitory activities of the membrane peptide fractions decreased as the molecular weight increased. For instance, the $<1 \mathrm{kDa}$ fraction had significantly $(\mathrm{P}<0.05)$ the highestt ACE-inhibitory activity (80\%) while the 5-10 kDa had the lowest activity $(45 \%)$. The current finding agrees with various studies (Aluko \& Monu 2003; Kuba et al., 2005; Wang et al., 2011) that have also reported a high ACE-inhibitory activity for the low molecular weight peptides when compared to larger size peptides. Comparatively, the present study established that the enzymatic hydrolysis employed for the production of $\mathrm{WCH}$ released peptides with higher ACE-inhibitory activity (45-80\%) than the unhydrolyzed WCI protein (37\%). The results are consistent with the presence of amino acid sequences that are encrypted within the primary sequence of food proteins (Udenigwe, 2013). These encrypted peptides (cryptides) are inactive when present as a structural component of the protein, hence lower ACE-inhibitory activity of the WCI when compared to WCH where the peptides have been released by pancreatin hydrolysis. The ACE-inhibition value $(75 \%)$ recorded in this current study for $\mathrm{WCH}$ is higher than the 48,50 , and $52-80 \%$ reported for papain-treated hemp seed (Malomo et al., 2015), sweet potato (Ishiguro et al., 2012) and Alcalase-treated Parkia speciosa seed (Siow \& Gan, 2013) protein hydrolysates, respectively.

In contrast to the ACE-inhibitory results, renin inhibition was directly related to peptide size of the ultrafiltration fractions (Fig. $4 \mathrm{~b})$. For instance, the $5-10 \mathrm{kDa}$ protein fractions had the highest renin inhibitory activity $(90 \%)$, while the $<1 \mathrm{kDa}$ fractions had the lowest $(50 \%)$ activity. The present results further suggest that the mode of peptide inhibition are different for the two enzymes (renin and ACE). The results also established that shorter chain peptides released during enzymatic hydrolysis of proteins are more effective renin-inhibitory agents when compared to the unhydrolyzed proteins. Therefore, together with the ACE data, the high renin-inhibitory activity of peptide fractions confirms the presence of cryptides within the primary sequence of the wonderful proteins. Since mammalian blood pressure is highly regulated by enzymes of the renin-angiotensin system, the observed in vitro inhibition of ACE and renin activities by the wonderful cola protein-derived peptides 
a

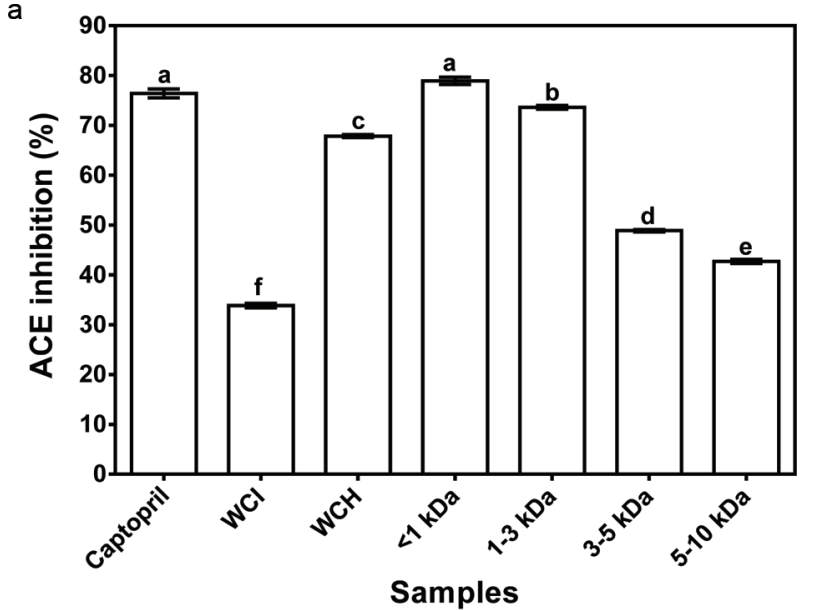

b

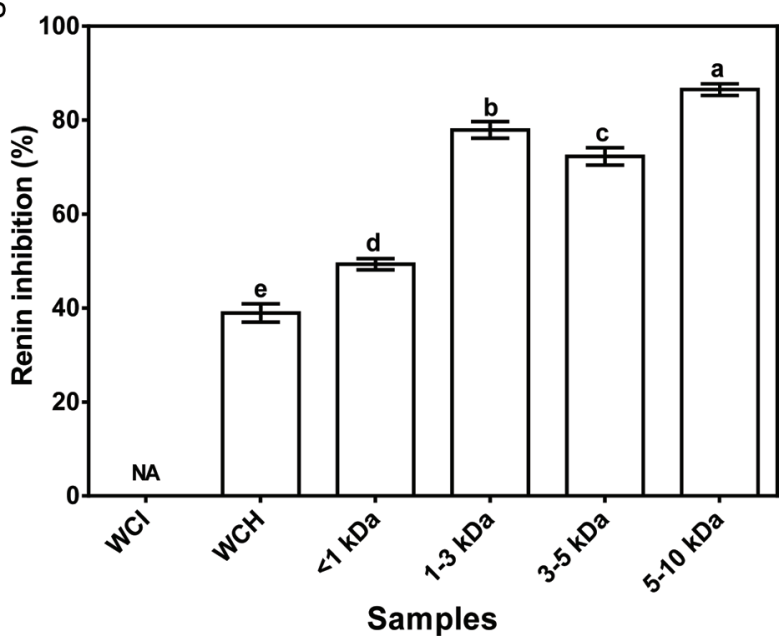

Figure 4. Inhibition of in vitro activities of ACE (a) and renin (b) by wonderful cola protein isolate $(\mathrm{WCl})$, hydrolysate $(\mathrm{WCH})$ and ultrafiltration fractions.

suggest potential use for hypertension management, hence the peptides were orally administered to SHRs.

\subsection{Blood pressure-reducing activities in SHRs}

The results of single oral administration ( $200 \mathrm{mg} / \mathrm{kg}$ b.w.) to SHRs show that the $<1$ and $1-3 \mathrm{kDa}$ protein fractions produced the maximum SBP reductions of -33 and $-31 \mathrm{mmHg}$ at $6 \mathrm{~h}$, respectively, but the effect gradually decreased to -12 and $-17 \mathrm{mmHg}$ at $24 \mathrm{~h}$ (Fig. 5a). Meanwhile, the 3-5 and 5-10 kDa fractions had maximum SBP reduction of -27 and $-28 \mathrm{mmHg}$ at $6 \mathrm{~h}$ and $8 \mathrm{~h}$, after which the effect gradually decreased to -16 and $-17 \mathrm{mmHg}$ at 24 $\mathrm{h}$, respectively. Interestingly, the $5-10 \mathrm{kDa}$ had a significantly $(\mathrm{P}<$ $0.05)$ weaker SBP-reducing effect after $2 \mathrm{~h}$, which suggests slower entry into blood circulation when compared to the smaller size peptides. However, all the peptide fractions were significantly ( $\mathrm{P}$ $<0.05)$ more effective as SBP-reducing agents than WCH. Therefore, ultrafiltration may have served as an effective refining agent that produced distinct peptide fractions with stronger synergistic effects for lowering SBP. Since the WCH contained a wider variety of peptides when compared to the peptide fractions, the results indicate that narrow size ranges enhanced SBP-reducing effect of the wonderful cola peptides. However, the peptides had delayed effect when compared to captopril (antihypertensive drug), which produced a significantly $(\mathrm{P}<0.05)$ stronger SBP-reducing effect after $2 \mathrm{~h}$. The delayed effect of these peptide fractions may be due to the need for additional hydrolysis in the gastrointestinal tract to release new potent peptide fragments particularly from biggersize peptides. It is also possible that absorption rate of captopril is higher than those of the peptides. The present reductions in SBP are similar to those previously reported for hemp seed (Malomo et al., 2015), sweet potato (Ishiguro et al., 2012), pistachio (Li et al., 2014) and almond (Wang et al., 2011) protein hydrolysates, even at higher doses than the amount used for the wonderful cola peptides. In contrast to the peptide products, the WCI that contained unhydrolyzed proteins was not effective in reducing SBP of the SHRs. The results are consistent with the presence of free bioactive cryptides within the peptide products and the observed stronger levels of ACE and renin inhibitions. Therefore, the very weak SBP-reducing effect of WCI is consistent with the need for extensive proteolysis within the gastrointestinal tract in order to release the bioactive cryptides. Similar results showing very weak effects of protein isolates have been reported for other seed proteins (Girgih et al., 2011b; Li et al. 2011).

Results of the DBP-reducing activity were similar to those observed for SBP reduction with the peptide fractions, especially the smallest sizes of $<3 \mathrm{kDa}$ having stronger effects than bigger-size peptides (Fig. 5b). However, unlike the SBP-reducing effects, the 3-5 and 5-10 $\mathrm{kDa}$ fractions were not very effective in reducing DBP. While the influence of other factors such as peptide absorption and enzyme inhibition cannot be discounted, the stronger DBP-reducing ability of $<1$ and $1-3 \mathrm{kDa}$ peptides may be due to the higher levels of arginine when compared to those of 3-5 and 5-10 $\mathrm{kDa}$ peptides. This is because arginine is a precursor of nitric oxide, which enhances vasorelaxation and will favor reduced DBP. A previous report has confirmed that increased nitric oxide production was directly related to the antihypertensive effect of a peptide (Ko et al., 2012). Consistent with the SBP reduction data, the WCI and WCH had weaker DBP-reducing effects, which can be attributed to reduced level of free bioactive cryptides and wide variation of peptide sizes, respectively, as discussed above. The present findings suggest that the low renin-inhibition potency of the $<1$ $\mathrm{kDa}$ peptides may have been compensated for by the high ACEinhibitory activity, hence strong SBP and DBP reductions observed for this fraction. The lack of direct correlations between in vitro and in vivo activities of the bioactive peptide fractions have also been previously reported for other protein hydrolysates (Malomo et al., 2015; Alashi et al., 2014b; He et al., 2013b).

\section{Conclusions}

For the first time, the present work confirmed the presence of bioactive cryptides within the primary structure of wonderful cola proteins. Pancreatin was successfully used to release these cryptides, which was collected as a hydrolysate. Ultrafiltration membrane process was used to separate the hydrolysate into peptide fractions with in vitro antioxidant capacity, in vitro RAS enzyme inhibitory activities and strong in vivo antihypertensive effects in SHRs. The ability to scavenge free radicals and bind metal cations could have contributed to antihypertensive effects since oxidative stress promotes hypertension. The hydrolysate and its membrane separated fractions possessed high contents of charged and hydrophobic amino acid residues, which may have contributed to their 
a

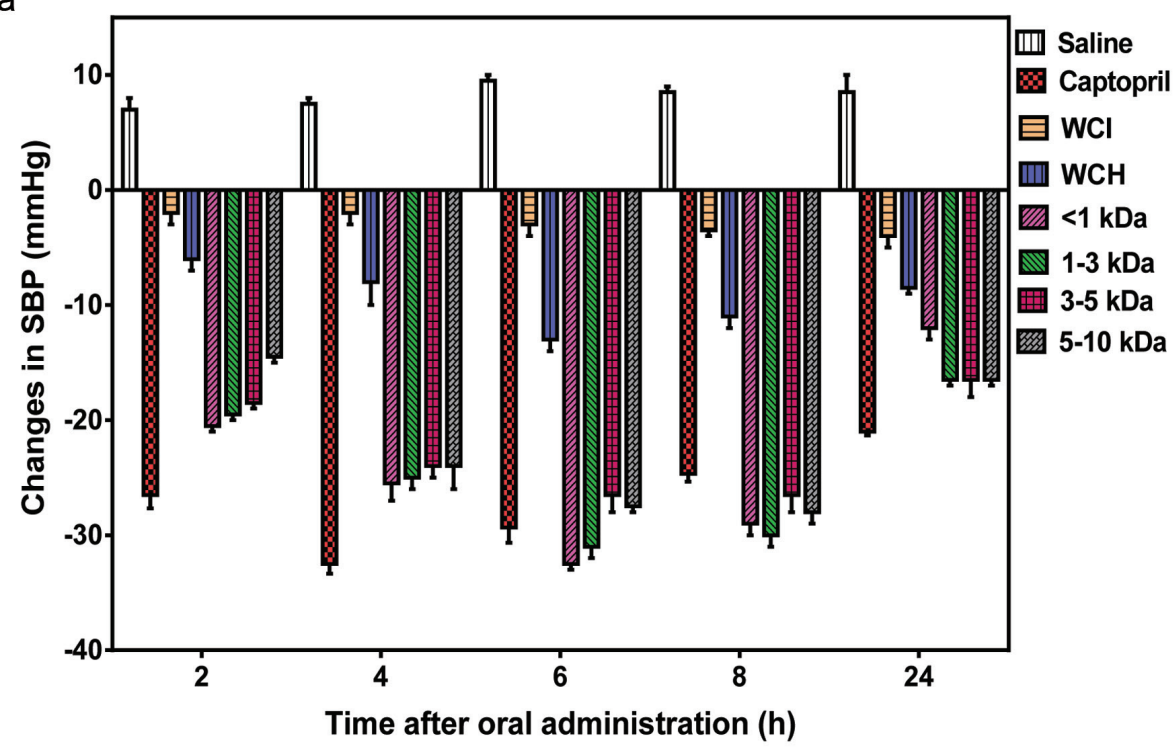

b

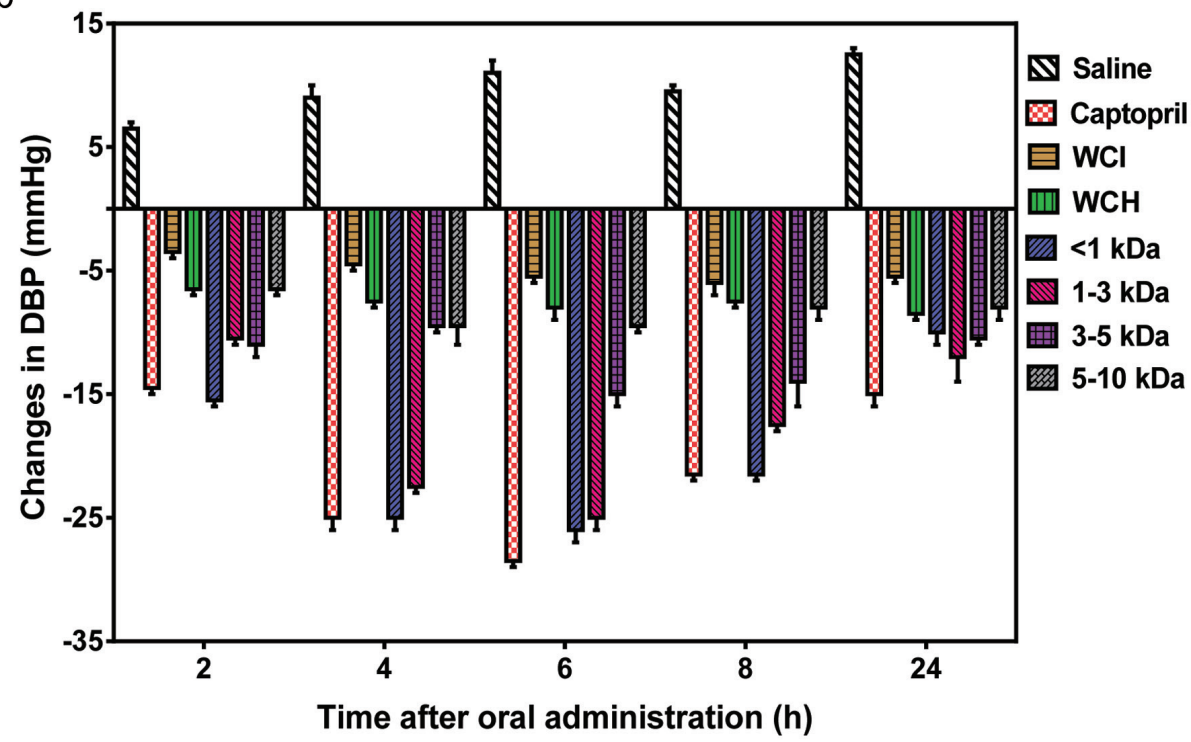

Figure 5. Antihypertesnive effects of wonderful cola protein isolate (WCI), hydrolysate (WCH) and ultrafiltration fractions after oral administration to spontaneously hypertensive rats. (a) Systolic blood pressure (SBP); (b) Diastolic blood pressure (DBP).

strong bioactivity potentials. The study also revealed the efficacy and importance of low molecular weight compounds in influencing a faster and higher bioactivity levels, especially for blood pressure reduction. These findings evidence the superior bioactive properties of pre-digested proteins when compared to whole proteins. The release of physiologically active principles from enzymatic processing of the underutilized and underexploited wonderful cola crop provides a platform for further development of high-value functional food products.

\section{Acknowledgments}

Dr O.S. Ijarotimi was a recipient of the Nigerian Tertiary Education Trust Fund (TETFund) PhD study Fellowship grant. We acknowledge the support of the Natural Sciences and Engineering Council of Canada (NSERC), funding reference number $R G$ $P I N-249890-13$. Cette recherche a été financée par le Conseil de recherches en sciences naturelles et en génie du Canada (CRSNG), numéro de référence $R G P I N-249890-13$.

\section{References}

Acharya, K.R., Sturrock, E.D., Riordan, J.F., and Ehlers, M.R.W. (2003). ACE revisited: a new target for structure-based drug design. Nature Rev. 2: 891-902.

Adisa, R.A., Choudhary, M.J., and Olorunsogo, O.O. (2010). Hypoglycemic activity of Buchholzia coriacea (Capparaceae) seeds in streptozotocin-induced diabetic rats and mice. Exp. Toxicol. Pathol. 63: 619-625. 
Ajaiyeoba, E.O., Onocha, P.A., and Olanrewaju, O.T. (2001). In vitro antihelminthic properties of Buchholzia coriacea and Gynandropsis gynandra. Pharm. Biol. 39: 217-220.

Ajibola, C.F., Fashakin, J.B., Fagbemi, T.N., and Aluko, R.E. (2011). Effect of peptide size on antioxidant properties of African yam bean seed (Sphenostylis stenocarpa) protein hydrolysate fractions. Int. J. Mol. Sci. 12: 6685-6702.

Alashi, A.M., Blanchard, C.L., Mailer, R.J., Agboola, S.O., Mawson, A.J., He, R., Girgih, A.T., and Aluko, R.E. (2014a). Antioxidant properties of Australian canola meal protein hydrolysates. Food Chem. 146: 500-506.

Alashi, A.M., Blanchard, C.L., Mailer, R.J., Agboola, S.O., Mawson, A.J., He, R., Malomo, S.A., Girgih, A.T., and Aluko, R.E. (2014b). Blood pressure lowering effects of Australian canola protein hydrolysates in spontaneously hypertensive rats. Food Res. Int. 55: 281-287.

Aleman, A., Perez-Santin, E., Bordenave-Juchereau, S., Arnaudin, I., Gomez-Guillen, M.C., and Montero, P. (2011). Squid gelatin hydrolysates with antihypertensive, anticancer and antioxidant activity. Food Res. Int. 44: 1044-1051.

Aluko, R.E., and Monu, E. (2003). Functional and bioactive properties of quinoa seed protein hydrolysates. J Food Sci. 68: 1254-1258.

Arise, A.K., Alashi, A.M., Nwachukwu, I.D., Malomo, S.A., Aluko, R.E., and Amonsou, E. (2016). Inhibitory properties of bambara protein hydrolysate and its membrane fractions against angiotensin converting enzymes, renin and free radicals. J. Sci. Food Agric. 97: 2834-2841.

Aukema, H.M., Gauthier, J., Roy, M., Jia, Y., Li, H., and Aluko, R.E. (2011). Distinctive effects of plant protein sources on renal disease progression and associated cardiac hypertrophy in experimental kidney disease. Mol. Nutr. Food Res. 55: 1044-1051.

Bidlingmeyer, B.A., Cohen, S.A., and Tarvin, T.L. (1984). Rapid analysis of amino acids using pre-column derivatization. J. Chrom. 336: 93-104.

Ezekiel, O.O., and Onyeoziri, N.F. (2009). Preliminary studies on the antimicrobial properties of Buchholzia coriacea (wonderful kola). Afr. J. Biotechnol. 8: 472-474.

Fred-Jaiyesimi, A.A., Adepoju, A., and Egbebunmi, O. (2011). Anthelmintic activities of chloroform and methanol extracts of Buchholzia coriacea Engle Seed. Parasitol. Res. 109: 441-444.

Gehrke, C.W., Wall, L.L., Absheer, J.S., Kaiser, F.E., and Zumwalt, R.W. (1985). Sample preparation for chromatography of amino acids: acid hydrolysis of proteins. J. Assoc. Official Anal. Chem. 68: 811-821.

Girgih, A.T., Alashi, A.M., He, R., Malomo, S.A., Raj, P., Netticadan, T., and Aluko, R.E. (2014a). A novel hemp seed meal protein hydrolysate reduces oxidative stress factors in spontaneously hypertensive rats. Nutrients 6: 5652-5666.

Girgih, A.T., Alashi, A.M., He, R., Malomo, S.A., and Aluko, R.E. (2014b). Structural and functional characterization of hemp seed (Cannabis sativa L.) protein-derived antioxidant and antihypertensive peptides. J. Funct. Foods 6: 384-394.

Girgih, A.T., Udenigwe, C.C., and Aluko, R.E. (2013). Reverse-phase HPLC separation of hemp Seed (Cannabis sativa L.) protein hydrolysate produced peptide fractions with enhanced antioxidant capacity. Plant Foods Hum. Nutr. 68: 39-46.

Girgih, A.T., Udenigwe, C.C., and Aluko, R.E. (2011a). In vitro antioxidant properties of hemp seed (Cannabis sativa L.) protein hydrolysate fractions. J. Am. Oil Chem. Soc. 88: 381-389.

Girgih, A.T., Udenigwe, C.C., Li, H., Adebiyi, A.P., and Aluko, R.E. (2011b). Kinetics of enzyme inhibition and antihypertensive effects of hemp seed (Cannabis sativa L.) protein hydrolysates. J. Am. Oil Chem. Soc. 88: 1767-1774.

He, R., Girgih, A.T., Malomo, S.A., Ju, X., and Aluko, R.E. (2013a). Antioxidant activities of enzymatic rapeseed protein hydrolysates and the membrane ultrafiltration fractions. J. Funct. Foods 5: 219-227.

He, R., Alashi, A., Malomo, S.A., Girgih, A.T., Chao, D., Ju, X., and Aluko, R.E. (2013b). Antihypertensive and free radical scavenging properties of enzymatic rapeseed protein hydrolysates. Food Chem. 141: 153-159.

Holmquist, B., Bunning, P., and Riordan, J.F. (1979). A continuous spectrophotometric assay for angiotensin converting enzyme. Anal. Biochem. 95: 540-548.

Huang, D., Ou, B., and Prior, R.L. (2005). The chemistry behind antioxidant capacity assays. J. Agric. Food Chem. 53: 1841-1856.

ljarotimi, S.O., Malomo, S.A., Fagbemi, T.N., Osundahunsi, O.F., and Aluko, R.E. (2018). Structural and functional properties of Buchholzia coria- cea seed flour and protein concentrate at different $\mathrm{pH}$ and protein concentrations. Food Hydrocolloids 74: 275-288.

Ishiguro, K., Sameshima, Y., Kume, T., Ikeda, K., Matsumoto, J., and Yoshimoto, M. (2012). Hypotensive effect of a sweet potato protein digests in spontaneously hypertensive rats and purification of angiotensin Iconverting enzyme inhibitory peptides. Food Chem. 131: 774-779.

Jamdar, S.N., Rajalakshmi, V., and Sharma, A. (2012). Antioxidant activity and ACE inhibitory properties of poultry viscera protein hydrolysate and its peptide fractions. J. Food Biochem. 36: 494-501.

Jamdar, S., Rajalakshmi, V., Pednekar, M., Juan, F., Yardi, V., and Sharma, A. (2010). Influence of degree of hydrolysis on functional properties, antioxidant activity and ACE inhibitory activity of peanut protein hydrolysate. Food Chem. 121: 178-184.

Je, J., Park, P., Byun, H., Jung, W., and Kim, S. (2005). Angiotensin I converting enzyme (ACE) inhibitory peptide derived from the sauce of fermented blue mussel Mytilus edulis. Bioresource Technol. 96: 1624-1629.

Jimsheena, V.K., and Gowda, L.R. (2011). Angiotensin I-converting enzyme (ACE) inhibitory peptides derived from arachin by simulated gastric digestion. Food Chem. 125: 561-569.

Ko, S.-C., Kim, D.G., Han, C.-H., Lee, Y.J., Lee, J.-K., Byun, H.-G., Lee, S.-C., Park, S.-J., Lee, D.-H., and Jeon, Y.-J. (2012). Nitric oxide-mediated vasorelaxation effects of anti-angiotensin I-converting enzyme (ACE) peptide from Styela clava flesh tissue and its anti-hypertensive effect in spontaneously hypertensive rats. Food Chem. 134: 1141-1145.

Kregel, K.C., and Zhang, H.J. (2007). An integrated view of oxidative stress in aging: Basic mechanisms, functional effects, and pathological considerations. Am. J. Physiol. Regul. Integr. Comp. Physiol. 292: 18-36.

Kuba, M., Tanaka, C., Tawata, S., and Yasuda, M. (2005). Production of angiotensin I-converting enzyme inhibitory peptides from soybean protein with Monascus purpureus acid proteinase. Process Biochem. 40: 2191-2196.

Landry, J., and Delhaye, S. (1992). Simplified procedure for the determination of tryptophan of foods and feedstuffs from barytic hydrolysis. J. Agric. Food Chem. 40: 776-779.

Li, P., Jia, J., Fang, M., Zhang, L., Guo, M., Xie, J., Xia, Y., Zhou, L., and Wei, D. (2014). In vitro and in vivo ACE inhibitory of pistachio hydrolysates and in silico mechanism of identified peptide binding with ACE. Process Biochem. 49: 898-904.

Li, H., Prairie, N., Udenigwe, C.C., Adebiyi, A.P., Tappia, P.S., Aukema, H.M., Jones, P.J.H., and Aluko, R.E. (2011). Blood pressure lowering effect of a pea protein hydrolysate in hypertensive rats and humans. J. Agric. Food Chem. 59: 9854-9860.

Mäkinen, S., Johannson, T., Gerd, E.V., Pihlava, J.M., and Pihlanto, A. (2012). Angiotensin I-converting enzyme inhibitory and antioxidant properties of rapeseed hydrolysates. J. Funct. Foods 4: 575-583.

Malomo, S.A., Onuh, J.O., Girgih, A.T., and Aluko, R.E. (2015). Structural and antihypertensive properties of enzymatic hemp seed protein hydrolysates. Nutrients 7: 7616-7632.

Markwell, M.A.K., Haas, S.M., Bieber, L.L., and Tolbert, N.E. (1978). Modification of Lowry procedure to simplify protein determination in membrane and lipoprotein samples. Anal. Biochem. 87: 206-210.

Nabha, L., Garbern, J.C., Buller, C.L., and Charpie, J.R. (2005). Vascular oxidative stress precedes high blood pressure in spontaneously hypertensive rats. Clin. Exp. Hypertens. 27: 71-82.

Naik, G.H., Priyadarsini, K.I., Satav, J.G., Banavalikar, M.M., Sohoni, P.P., and Biyani, M. (2003). Comparative antioxidant activity of individual herbal components used in Ayurvedic medicine. Phytochem. 63: 97-104.

Naqash, S.Y., and Nazeer, R.A. (2011). Evaluation of bioactive peptides isolated from Exocoetus volitans backbone. Int. J. Food Sci. Technol. 46: 37-43.

Nwachukwu, I.D., Girgih, A.T., Malomo, S.A., Onuh, J.O., and Aluko, R.E. (2014). Thermoase-derived flaxseed protein hydrolysates and membrane ultrafiltration peptide fractions have systolic blood pressurelowering effects in spontaneously hypertensive rats. Int. J. Mol. Sci. 15: 18131-18147.

Pastor, N., Weinstein, H., Jamison, E., and Brenowitz, M. (2000). A detailed interpretation of $\mathrm{OH}$ radical footprints in a TBP DNA complex reveals the role of dynamics in the mechanism of sequence specific binding. J. Mol. Biol. 304: 55-68. 
Pickering, T.G., Hall, J.E., Appel, L.J., Falkner, B.E., Graves, J., Hill, M.N., Jones, D.W., Kurtz, T., Sheps, S.G., and Roccella, E.J. (2005). Recommendations for blood pressure measurement in humans and experimental animals. Part 1: Blood pressure measurement in humans. Circulation 111: 697-716.

Ren, J., Zhao, M., Shi, J., Wang, J., Jiang, Y., Cui, C., Kakuda, Y., and Xue, S.J. (2008). Purification and identification of antioxidant peptides from grass carp muscle hydrolysates by consecutive chromatography and electrospray ionization-mass spectrometry. Food Chem. 108 727-736.

Sakanaka, S., Tachibana, Y., and Okada, Y. (2005). Preparation and antioxidant properties of extracts of Japanese persimmon leaf tea (kakinoha-cha). Food Chem. 89: 569-575.

Sarmadi, B.H., and Ismail, A. (2010). Antioxidative peptides from food proteins: A review. Peptides 31: 1949-1956.

Segall, L., Covic, A., and Goldsmith, D.J.A. (2007). Direct renin inhibitors: the dawn of a new era, or just a variation on a theme? Nephrol. Dialysis, Transpl. 22: 2435-2439.

Segura, C.M.R., Chel, L.A., and Betancur, D.A. (2010). Angiotensin-I converting enzyme inhibitory and antioxidant activities of peptide fractions extracted by ultrafiltration of cowpea Vigna unguiculata hydrolysates. J. Sci. Food Agric. 90: 2512-2518.

Simão, S., Gomes, P., Pinto, V., Silva, E., Amaral, J.S., Igreja, B., Alfonso, J. Serrão, M.P., Pinho, M.J., and Soares-da-Silva, P. (2011). Age-related changes in renal expression of oxidant and antioxidant enzymes and oxidative stress markers in male SHR and WKY rats. Exp. Gerontol. 46: 468-474.

Sheih, I., Wu, T., and Fang, T. (2009). Antioxidant properties of a new antioxidative peptide from algae protein waste hydrolysate in different oxidation systems. Bioresource Technol. 100: 3419-3425.

Siddeeg, A., Xu, Y., Jiang, Q., and Xia, W. (2015). In vitro antioxidant activity of protein fractions extracted from seinat (Cucumis melo var. tibish) seeds. CyTA J. Food 13: 472-481.

Siow, H., and Gan, C. (2013). Extraction of antioxidative and antihypertensive bioactive peptides from Parkia speciosa seeds. Food Chem. 141: 3435-3442.

Tang, X.Y., He, Z.Y., Dai, Y.F., Xiong, Y.L., Xie, M.Y., and Chen, J. (2010). Peptide fractionation and free radical scavenging activity of zein hydrolysate. J. Agric. Food Chem. 58: 587-593.
Udenigwe, C.C. (2013). In silico analysis of the large and small subunits of cereal RuBisCO as precursors of cryptic bioactive peptides. Process Biochem. 48: 1794-1799.

Udenigwe, C.C., Lin, Y.S., Hou, W.C., and Aluko, R.E. (2009). Kinetics of the inhibition of renin and angiotensin I-converting enzyme by flaxseed protein hydrolysate fractions. J. Funct. Foods 1: 199-207.

Valdez-Ortiz, A., Fuentes-Gutiérrez, C.I., Germán-Báez, L.J., Gutiérrez-Dorado, R., and Medina-Godoy, S. (2012). Protein hydrolysates obtained from Azufrado (sulphur yellow) beans (Phaseolus vulgaris): Nutritional, ACE-inhibitory and antioxidative characterization. LWT-Food Sci. Technol. 46: 91-96.

Wang, C., Tian, J., and Wang, Q. (2011). ACE inhibitory and antihypertensive properties of apricot almond meal hydrolysate. Eur. Food Res. Technol. 232: 549-556.

Wang, J.S., Zhao, M., Zhao, Q.Z., and Jiang, Y.M. (2007). Antioxidant properties of papain hydrolysates of wheat gluten in different oxidation systems. Food Chem. 101: 1658-1663.

Winczura, A., Zdzalik, D., and Tudek, B. (2012). Damage of DNA and proteins by major lipid peroxidation products in genome stability. Free Radic. Res. 46: 442-459.

World Health Organization. (2013). A global brief on hypertension; silent killer, global public health crisis. Geneva, USA. WHO/DCO/ WHD/2013.2. 40pp. Internet: http://www.who.int/cardiovascular diseases/publications/global_brief_hypertension/en/ (accessed July 04, 2018)

Xia, Y., Bamdad, F., Gänzle, M., and Chen, L. (2012). Fractionation and characterization of antioxidant peptides derived from barley glutelin by enzymatic hydrolysis. Food Chem. 134: 1509-1518.

Xie, Z., Huang, J., Xu, X., and Jin, Z. (2008). Antioxidant activity of peptides isolated from alfalfa leaf protein hydrolysate. Food Chem. 111 370-376.

You, S.J., Udenigwe, C.C., Aluko, R.E., and Wu, J. (2010). Multifunctional peptides from egg white lysozyme. Food Res. Int. 43: 848-855.

Zhang, S.B., Wang, Z., and Xu, S.Y. (2008). Antioxidant and antithrombotic activities of rapeseed peptides. J. Am. Oil Chem. Soc. 85: 521-527.

Zhu, Z., Qiu, N., and Yi, J. (2010). Production and characterization of an giotensin converting enzyme (ACE) inhibitory peptides from apricot (Prunus armeniaca L.) kernel protein hydrolysate. Eur. Food Res. Technol. 231: 13-19. 